\title{
Pelaksanaan Pembelajaran Literasi di SMP Negeri 1 Jember Tahun
} 2019

\section{Implementation of Literation Learning in State Middle School 1 Jember Year 2019}

\author{
Isnaniatul Lailiyah ${ }^{1}$ \\ Email: isnaniatul1077@gmail.com \\ ${ }_{1}^{1}$ MTsN 9 Jember
}

\section{INFORMASI ARTIKEL \\ Diterima: 4 Mei 2021 \\ Direvisi: 4 Juni 2021 \\ Publikasi Online: 30 Juni 2021}

\section{KATA KUNCI}

Pembelajaran Literasi, Membaca, Budaya dan Kewargaan

\section{A B S T R A C T}

Literacy learning is an activity, a program implemented by schools to train students to have extensive reading, insight, and information about many things. This is doing by students in other to have critical thinking about what they have read. On the other hand literacy learning is done not only by reading, but also by writing. Reading and writing become a unity in the implementation of literacy learning. The purpose of this study is to describe the implementation of reading literacy learning in SMP Negeri 1 Jember and describe the implementation of cultural and citizenship literacy learning at SMP Negeri 1 Jember. This study uses a qualitative approach and descriptive research type. The location of this research is in SMP Negeri 1 Jember. Determination of informants using purposive techniques. Data collection techniques with interviews, observation and documentation. Data analysis uses the interactive model of Miles, Huberman and Saldana. The validity of the data uses technical triangulation and source triangulation. The results of this study indicate the implementation of reading literacy learning is carried out with several activities, namely learning to read silent reading literacy, reading literacy 4 books every 1 semester, learning literacy reading with a mandatory library visit day system, learning literacy reading outside the classroom, and making reading corners and implementing learning cultural and citizenship literacy is carried out with several activities, namely the implementation of literacy presentations, class mading competitions, literacy competitions to write poems on the Heroes' Day and Youth Pledge, cultural literacy exhibitions, and book fairs. 


\begin{abstract}
A B S T R A K
Pelaksanaan pembelajaran literasi adalah suatu kegiatan, program yang dilaksanakan sekolah untuk melatih siswa agar mempunyai bekal bacaan, wawasan, informasi yang luas mengenai banyak hal. Hal ini dilakukan supaya siswa mempunyai pemikiran yang kritis terhadap apa saja yang telah mereka baca. Disisi lain pelaksanaan pembelajaran literasi yang dilakukan bukan membaca saja, tetapi juga menulis. Membaca dan menulis menjadi satu kesatuan dalam pelaksanaan pembelajaran literasi. Tujuan penelitian ini yaitu untuk mendeskripsikan pelaksanaan pembelajaran literasi membaca di SMP Negeri 1 Jember dan mendeskripsikan pelaksanaan pembelajaran literasi budaya dan kewargaan di SMP Negeri 1 Jember. Penelitian ini menggunakan pendekatan kualitatif dan jenis penelitian deskripstif. Lokasi penelitian ini di SMP Negeri 1 Jember. Penentuan informan menggunakan teknik purposive. Teknik pengumpulan data dengan wawancara, observasi dan dokumentasi. Analisis data menggunakan model interaktif Miles, Huberman dan Saldana. Keabsahan data mengunakan triangulasi teknik dan triangulasi sumber. Hasil penelitian ini menunjukkan pelaksanaan pembelajaran literasi membaca dilakukan dengan beberapa kegiatan yaitu pembelajaran literasi membaca senyap, literasi membaca 4 buku setiap 1 semester, pembelajaran literasi membaca dengan sistem hari wajib berkunjung perpustakaan, pembelajaran literasi membaca di luar kelas, dan membuat pojok baca dan pelaksanaan pembelajaran literasi budaya dan kewargaan dilakukan dengan beberapa kegiatan yaitu pelaksanaan literasi presentasi, lomba mading kelas, lomba literasi menulis puisi tema hari pahlawan dan sumpah pemuda, pameran literasi budaya, dan bazar buku.
\end{abstract}

(C) Heritage: Journal of Social Studies Institut Agama Islam Negeri Jember, Indonesia

https://doi.org/ 10. $x x x x / x x x x x$

This is an open access article under the CC-BY-SA license

\title{
Pendahuluan
}

Pendidikan merupakan usaha sadar yang sudah terencana secara sistematis untuk mewujudkan proses kegiatan belajar mengajar yang menyenangkan bagi peserta didik dan pendidik agar bisa mengembangkan potensi, keterampilan yang dimilikinya. Menurut Aziz, (2018) pendidikan adalah proses sepanjang hayat dan perwujudan, pembentukan diri secara utuh dalam pengembangan segenap potensi dalam rangka pemenuhan semua komitmen manusia sebagai individu, makhluk sosial dan sebagai makhluk Tuhan. Dalam pendidikan, secara implisit terjalin hubungan antara dua pihak, yaitu pihak pendidikan dan pihak peserta didik yang di dalam hubungan itu berlainan kedudukan dan peranan setiap pihak, akan tetapi sama dalam hal dayanya yaitu saling mempengaruhi guna 
terlaksanya proses pendidikan (transformasi pendidikan, nilai-nilai dan keterampilanketerampilan yang tertuju kepada tujuan-tujuan yang diinginkan.

Menurut Kemendikbud (2016) Indonesia tercatat sebagai salah satu negara yang berhasil mengurangi angka buta huruf. Data UNDP tahun 2014 mencatat bahwa tingkat kemelekhurufan masyarakat Indonesia mencapai 92,8\% untuk kelompok dewasa, dan 98,8\% untuk kategori remaja. Capaian ini sebenarnya menunjukkan bahwa Indonesia telah melewati tahapan kritis literasi dalam pengertian kemelekhurufan. Meskipun demikian, tantangan yang saat ini dihadapi adalah rendahnya minat baca. Selain ketersediaan buku diseluruh Indonesia belum memadai, pemerintah juga menghadapi rendahnya motivasi membaca di kalangan peserta didik. Hal ini memprihatinkan karena diera teknologi informasi, peserta didik dituntut untuk memiliki kemampuan membaca dalam pengertian memahami teks secara analitis, kritis, dan reflektif.

Menurut Abidin (2017) hasil penilaian kemampuan membaca yang dilakukan oleh programme for International Student Assessment (PISA) menunjukkan hal yang sama, yakni Indonesia merupakan negara dengan tingkat kemampuan membaca yang rendah. Berdasarkan penilaian PISA pada tahun 2000 diketahui bahwa Indonesia hanya memiliki skor 371, serta menduduki negara dengan kemampuan membaca terendah ketiga dari negara-negara yang dinilai. Pada tahun 2003 skor kemampuan membaca siswa di Indonesia sebesar 383 skor. Hasil tersebut menempatkan Indonesia pada peringkat ke 39 dari 40 negara. Pada tahun 2006 skor kemampuan membaca Indonesia sedikit meningkat yakni sebesar 393. Menurut Abidin (2017) berkaitan dengan rendahnya kemampuan literasi siswa di Indonesia, sejak tahun 2000 kemampuan membaca pemahaman, sebagai salah satu bagian dari kemampuan literasi.

Siswa SD, SMP di tanah air, sudah beberapa kali diukur dan dibandingkan dengan kemampuan siswa dibeberapa negara lain. Survei Progress in International Reading Literacy Study (PIRLS) yang dilakukan pada tahun 2011, siswa Indonesia masih menempati urutan bawah dibandingkan dengan negara lain yang diteliti. Kementerian Pendidikan dan Kebudayaan memaparkan bahwa pengembangan kurikulum 2013 diharapkan dapat menghasilkan insan Indonesia yang produktif, kreatif, inovatif, dan afektif melalui penguatan sikap, keterampilan, dan pengetahuan yang terintegrasi. Upaya ini sangat beralasan sejalan dengan kenyataan bahwa berbagai penelitian dan survei yang dilakukan oleh beberapa lembaga internasional selalu menempatkan Indonesia pada urutan terendah, dalam bidang kemampuan literasi dibandingkan dengan beberapa negara ASEAN sekalipun. 
Dari permasalahan yang dialami siswa Indonesia dalam hal membaca, Kementerian pendidikan dan kebudayaan menetapkan upaya untuk meningkatkan kemampuan membaca pada siswa. Upaya tersebut yakni Gerakan Literasi Sekolah (GLS). Menurut Abidin (2017) GLS merupakan suatu usaha atau kegiatan yang bersifat partisipatif, dengan melibatkan warga sekolah (peserta didik, guru, kepala sekolah, tenaga kependidikan, pengawas sekolah, komite sekolah, orangtua/wali murit peserta didik), akademisi, penerbit, media massa, masyarakat (tokoh masyarakat yang dapat merepresentasikan keteladanan, dunia usaha, dan lain sebagainya) serta pengakuan kepentingan di bawah koordinasi Direktorat Jenderal Pendidikan Dasar dan Menengah Kementerian Pendidikan dan Kebudayaan.

Menurut Pangesti (2016) program literasi ini sangat penting karena sebagian besar proses pendidikan tergantung pada kemampuan dan kesadaran literasi. Literasi merupakan sarana peserta didik dalam mengenal, memahami, dan menerapkan ilmu yang didapatnya di bangku sekolah. Literasi juga ada kaitannya dengan kehidupan peserta didik, baik di rumah maupun di lingkungan sekitarnya. Perkembangan zaman yang semakin maju menuntut manusia untuk memiliki pengetahuan dan wawasan yang luas untuk bisa bersaing di era modern ini. Khususnya bagi peserta didik sangat dituntut untuk mempunyai wawasan yang sangat luas. Pengetahuan tersebut didapatkan dari seberapa banyak seseorang membaca untuk mendapatkan informasi. Hal ini berkaitan dengan kemampuan membaca seseorang. Kemampuan membaca dan menulis seseorang memegang peranan penting dalam kesuksesan seseorang, karena setiap informasi dan wawasan yang diperoleh seseorang tidak terlepas dari kegiatan membaca dan menulis.

Berdasarkan hasil wawancara dengan koordinator literasi, pelaksanaan pembelajaran literasi di SMP Negeri 1 Jember diterapkan semenjak adanya peraturan dari kementerian berupa GLN (Gerakan Literasi Nasional) lalu dipersempit menjadi GLS (Gerakan Literasi Sekolah) dan lebih dipersempit lagi menjadi pembelajaran literasi. Program pelaksanaan pembelajaran literasi di sekolah mulai dilaksanakan karena melihat faktor anak-anak yang mulai kurang minat terhadap membaca. Anak-anak lebih suka bermain gadget dari pada membaca. Oleh karena itu, SMP Negeri 1 Jember ingin menjadikan siswanya menjadi siswa yang unggul dalam minat membaca dan untuk membudayakan membaca dan menulis. Sekalipun program literasi sudah menjadi aturan, namun pelaksanaan pembelajaran literasi tidak dilaksanakan oleh semua sekolah, hanya sekolah-sekolah tertentu saja yang melaksanakan pembelajaran literasi di sekolah. Hal ini karena dalam melaksanakan pembelajaran literasi juga diperlukan beberapa kesiapan dari sekolah itu sendiri. 
SMP Negeri 1 Jember sudah 3 tahun melakukan kegiatan literasi dan literasi yang diterapkan di SMP Negeri 1 Jember menarik dan bervariasi seperti melakukan kegiatan literasi berupa pembelajaran literasi membaca senyap, literasi membaca 4 buku setiap 1 semester, pembelajaran literasi membaca di luar kelas, pelaksanaan literasi presentasi, pameran literasi budaya, bazar buku, dan lain sebagainya. Hal ini mendorong peneliti tertarik untuk melakukan penelitian tentang "Pelaksanaan Pembelajaran Literasi di SMP Negeri 1 Jember Tahun 2019".

\section{Tinjauan literatur}

Pembelajaran Literasi

Secara tradisional, menurut Abidin (2017) literasi dipandang sebagai kemampuan membaca dan menulis. Orang yang dapat dikatakan literat dalam pandangan ini adalah orang yang mampu membaca dan menulis atau bebas buta huruf. Pengertian literasi selanjutnya berkembang menjadi kemampuan membaca, menulis, berbicara, dan menyimak. Sejalan dengan perjalanan waktu, definisi literasi telah bergeser dari pengertian yang sempit menuju pengertian yang lebih luas mencakup berbagai bidang penting lainnya. Perubahan ini disebabkan oleh berbagai faktor, baik faktor perluasan makna akibat semakin luas penggunanya, perkembangan teknologi informasi dan teknologi, maupun perubahan analogi. Literasi didefinisikan sebagai kemampuan untuk menggunakan bahasa dan gambar dalam bentuk yang kaya dan beragam untuk, membaca, menulis, mendengar, berbicara, melihat, menyajikan, dan berpikir kritis tentang ide-ide.

Menurut Dewi (2016) literasi secara luas dimaknai sebagai kemampuan mengakses, memahami, dan menggunakan sesuatu secara cerdas melalui berbagai aktivitas, antara lain membaca, melihat, menyimak, menulis, dan berbicara pembelajaran literasi.

Literasi adalah kemampuan berbahasa yang di dalamnya mencakup keterampilan membaca yang dimiliki seseorang untuk dapat dimanfaatkan bagi dirinya sendiri maupun kegiatan yang ada dalam masyarakat. Literasi tidak terpaku hanya pada arti kemampuan keberaksaraan seseorang. Karena keaksaraan mempunyai beragam arti yang tidak hanya bertumpu pada kemampuan keberaksaraan. Dengan itu makna literasi tidak lagi mengenai membaca dan menulis saja, namun mulai luas dengan bermacam jenis-jenis literasi.

Sebagaimana yang disampaikan Abidin (2015) pada abad ke-21 pendidikan di tuntut harus kreatif dalam berfikir, kritis dalam intelektual, etis dalam pergaulan dan berkarakter dalam berkehidupan. Begitupun untuk literasi pada abad ke 21, literasi berkembang menjadi kemampuan membaca, menulis, berbicara dan menyimak. 
Sedangkan jika dilihat secara tradisional, dipandang sebagai kemampuan membaca dan menulis. Pembelajaran literasi merupakan pembelajaran yang mengoptimalkan keterampilan-keterampilan literasi dalam mewujudkan suatu pembelajaran yang efektif. Keterampilan-keterampilan tersebut meliputi keterampilan membaca, keterampilan menyimak, keterampilan menulis, dan keterampilan berbicara.

Pembelajaran literasi di sekolah menurut Abidin (2015) dilaksanakan untuk mencapai tujuan tertentu. Sejalan dengan perkembangan definisi literasi, tujuan pembelajaran literasipun mengalami perubahan. Pada awalnya, pembelajaran literasi di sekolah hanya ditujukan agar siswa terampil menguasai dimensi linguistik literasi. Dimensi-dimensi lingustik yang diharapkan dapat dikuasai oleh siswa antara lain sistem bahasa, konteks bahasa, dan variasi bahasa. Dalam perkembangan selanjutnya, pembelajaran literasi ditujukan agar siswa mampu menguasai dimensi bahasa dan dimensi kognitif literasi (mencakup proses pemahaman, proses membaca, proses menulis, dan konsep analisis wacana tertulis).

Menurut Abidin (2015) pembelajaran literasi bertujuan untuk memperkenalkan anak-anak tentang dasar-dasar membaca, menulis, memelihara kesadaran bahasa, dan motivasi untuk belajar. Pembelajaran literasi pada jenjang sekolah menengah bertujuan untuk membawa peserta didik agar semakin memiliki motivasi untuk menumbuhkan minat berliterasi dalam dirinya guna meningkatkan minat baca dan menjadi pembelajar sepanjang hayat. Adapun tujuan pembelajaran literasi pada abad ke-21 yaitu membentuk peserta didik menjadi pembaca, penulis, dan komunikator yang strategis; meningkatkan kemampuan berpikir dan mengembangkan kebiasaan berpikir pada peserta didik; meningkatkan dan memperdalam motivasi belajar peserta didik; mengembangkan kemandirian peserta didik sebagai seorang pembelajar yang kreatif, inovatif, produktif, dan sekaligus berkarakter.

Menurut Dikdasmen (2016) literasi tidak dipisahkan dari dunia pendidikan. Literasi menjadi sarana peserta didik dalam mengenal, memahami, dan menerapkan ilmu yang didapatkannya di bangku sekolah. Literasi juga terkait dengan kehidupan peserta didik, baik di rumah maupun dilingkungan sekitarnya. Abidin (2017) mengungkapkan bahwa sejalan dengan berkembangnya teknologi informasi dan komunikasi guru di sekolah harus berpikir bahwa literasi merupakan sebuah konsep yang berkembang dan dapat dimanfaatkan sebagai media pembelajaran di kelas.

Menurut TIM GLN (2017) cakupan dimensi literasi terdiri dari 6 macam, yaitu literasi baca dan tulis, literasi numerasi, literasi sains, literasi digital, literasi finansial, dan literasi budaya dan kewargaan. Menurut Abidin (2017) literasi terdiri dari literasi matematika, literasi sains, literasi membaca, dan literasi menulis. Menurut Clay dan 
Ferguson yang dikutip (kemendikbud, 2016) menjabarkan bahwa literasi dibagi menjadi 6, yaitu literasi dini, literasi dasar, literasi perpustakaan, literasi media, literasi teknologi, dan literasi visual. Menurut Setyawan yang dikutip kemendikbud membagi literasi menjadi 9 yaitu, literasi kesehatan, literasi finansial, literasi digital, literasi data, literasi kritikal, literasi visual, literasi teknologi, literasi statistik, dan literasi informasi. Sedangkan Waskim yang dikutip kemendikbud membagi literasi dibagi menjadi 5 yaitu literasi dasar, literasi perpustakaan, literasi media, literasi teknologi, dan literasi visual.

Dimensi literasi menurut buku Panduan Gerakan Literasi Nasional (dalam Kemdikbud \& GLN, 2017), yaitu:

1) Literasi Baca dan Tulis

Literasi baca dan tulis adalah pengetahuan dan kecakapan untuk mambaca, menulis, mencari, menelusuri, mengolah, dan memahami informasi untuk menganalisis, menanggapi, dan menggunakan teks tertulis untuk mencapai tujuan, mengembangkan pemahaman dan potensi, serta untuk berpartisipasi di lingkungan sosial.

2) Literasi Numerasi

Literasi numerasi adalah pengetahuan dan kecakapan untuk bisa memperoleh, menginterpretasikan, menggunakan, dan mengomunikasikan berbagai macam angka dan simbol matematika untuk memecahkan masalah praktis dalam berbagai macam konteks kehidupan sehari-hari, bisa menganalisis informasi yang ditampilkan dalam berbagai bentuk (grafik, tabel, bagan, dan sebagainya) untuk mengambil keputusan.

3) Literasi Sains

Literasi sains adalah membangun sejumlah kompetensi yang harus dimiliki oleh setiap peserta didik. Bagian terpenting dalam membangun literasi sains adalah bagaimana fakta-fakta sains yang ada membentuk keterampilan-keterampilan tertentu dalam kegiatan pembelajaran. Dalam hal ini, literasi sains menjadi bagian tak terpisahkan dalam membentuk peserta didik menjadi warga yang aktif dan partisipatif dalam konteks dunia nyata, serta mampu memecahkan setiap permasalahan yang ada.

Dimensi literasi menurut Yunus Abidin salah satunya, yaitu:

a) Literasi Digital

Literasi digital adalah pengetahuan dan kecakapan untuk menggunakan media digital, alat-alat dalam menemukan, mengevaluasi, menggunakan, membuat informasi, dan memanfaatkannya secara sehat, baik, bijak, cerdas, cermat, tepat, dan patuh hukum dalam rangka membina komunikasi dan interaksi dalam kehidupan sehari-hari. 
b) Literasi Finansial

Literasi finansial adalah pengetahuan dan kecakapan untuk mengaplikasikan pemahaman tentang konsep dan resiko, keterampilan dan memotivasi dan pemahaman agar dapat membuat keputusan yang efektif dalam konteks finansial untuk meningkatkan kesejahteraan finansial, baik individu maupun sosial, dan dapat berpartisipasi dalam lingkungan masyarakat.

c) Literasi Budaya dan Kewargaan

Literasi budaya adalah pengetahuan dan kecakapan dalam memahami dan bersikap terhadap kebudayaan Indonesia sebagai identitas bangsa. Sementara itu, literasi kewargaan adalah pengetahuan dan kecakapan dalam memahami hak dan kewajiban warga masyarakat.

\section{Literasi Membaca}

Menurut Anderson (dalam Ahmad, 2016) mengatakan bahwa membaca merupakan suatu proses untuk memahami yang tersirat di dalam yang tersurat. Dengan kata lain, membaca sebagai suatu proses untuk melihat pikiran yang terkandung dalam kata-kata yang tertulis. Menurut Antoro (2017) Membaca salah satu aktivitas dalam kegiatan berliterasi merupakan kunci bagi kemajuan pendidikan. Ia jendela bagi masuknya beragam ilmu pengetahuan. Keberhasilan suatu pendidikan sedianya tidak diukur dari banyaknya anak yang mendapatkan nilai tinggi dalam suatu pelajaran, melainkan banyaknya anak yang gemar membaca disuatu kelas.

Menurut Abidin (2017) Membaca dalam konsep literasi ditafsirkan sebagai usaha memahami, menggunakan, merefleksi, dan melibatkan diri dalam berbagai jenis teks untuk mencapai suatu tujuan. Membaca bertujuan mengembangkan pengetahuan dan potensi seseorang, serta untuk berpartisipasi dalam masyarakat. Berdasarkan definisi ini membaca diartikan sebagai kegiatan membangun makna, menggunakan informasi dari bacaan secara langsung dalam kehidupan, dan mengaitkan informasi dari teks dengan pengalaman pembaca.

Kegiatan membaca membutuhkan kemampuan menganalisis dan menyintesis informasi, sehingga pemahaman yang dihasilkan memiliki struktur makna yang kompleks. Membaca juga harus dimanfaatkan untuk mengembangkan pengetahuan dan potensi pembaca sehingga orang tersebut mampu berpartisipasi dalam masyarakat. Partisipasi ini didasarkan atas teks yang berhasil dipahami secara utuh. Oleh sebab itu tes standar PISA senantiasa melibatkan aspek sosial sebagai salah satu bagian pengukuran kemampuan membaca. 
Pembelajaran literasi membaca dalam kegiatan yang dilakukan siswa ada 2 macam yaitu pembelajaran membaca pemahaman dan pembelajaran membaca cermat. Pembelajaran membaca pemahaman dapat diartikan sebagai serangkaian aktivitas yang dilakukan siswa untuk mencapai keterampilan membaca pemahaman. Pembelajaran membaca melibatkan seluruh aktivitas metal dan kemampuan berfikir siswa dalam memahami, mengkritisi, dan memproduksi sebuah wacana tertulis. Dalam pembelajaran membaca pemahaman, siswa diharapkan mampu memahami isi bacaan dengan melakukan serangkaian aktifitas yang dapat menunjang ketercapaian tujuan pembelajaran. Salah satu penelitian yang mengembangkan pembelajaran membaca berbasis metakognisi dilakukan oleh Rayner et al (dalam Yunus), penelitian yang mereka lakukan difokuskan untuk membantu siswa belajar membaca, mengetahui, dan memecahkan kesulitan membaca siswa.

Pembelajaran membaca cermat dapat diartikan sebagai serangkaian aktivitas yang di lakukan siswa untuk mencapai keterampilan membaca, yakni pemahaman literal, inferensial, dan pemahaman kritis atau evaluatif. Pembelajaran membaca cermat diorientasikan agar siswa mampu menganalisis isi teks baik bersifat ekplisit maupun implisit, menggambarkan inferensi analitis atas teks, mengkritisi teks melalui penggunaan logika berpikir yang benar, serta di tunjang dengan fakta-fakta yang lengkap dan tepat baik dari dalam teks maupun dari luar teks serta memproduksi secara kreatif pemahamannya melalui berbagai media representasional yang bersifat multimodal, multigenre, multimedia, dan multibudaya.

Berdasarkan konsep di atas, pembelajaran literasi membaca menuntut pembelajaran yang hendaknya dilakukan dengan berlandaskan pada pengembangan kemampuan siswa untuk berpikir tingkat tinggi. Ada beberapa sub keterampilan membaca yang harus di perhatikan agar keterampilan membaca berfungsi bagi penguasaan materi berbagai mata pelajaran. Keterampilan membaca memiliki beberapa sub yaitu: keterampilan memilih strategi membaca yang tepat, keterampilan memahami organisasi teks, keterampilan mengkritisi teks, keterampilan membangun makna kata.

Sejalan dengan tujuan utama pembelajaran literasi membaca yakni agar siswa memperoleh pemahaman yang mendalam, pembelajaran literasi membaca ditentukan pada aktivitas siswa agar siswa mampu menganalisis isi teks baik yang ekplisit maupun yang implisit. 
Guna mencapai tujuan pembelajaran literasi membaca dalam membina kebiasaan dan kemampuan membaca, proses pembelajaran literasi membaca secara garis besar harus terdiri dari tiga tahapan aktivitas, yakni aktivitas prabaca, aktivitas membaca, dan aktivitas pascabaca.

Di era pendidikan 4.0, minat baca siswa khususnya siswa di level sekolah dasar perlu ditingkatkan (Handayani et al., 2018). Era pendidikan 4.0 menjadi tantangan tersendiri tak terkecuali bagi pihak sekolah dasar dalam membentengi siswa dari dampak negatif derasnya penggunaan teknologi terutama dalam keseharian siswa. Era pendidikan 4.0 merupakan era modern dimana adanya sistem digitalisasi hampir dalam segala aspek kehidupan, tak terkecuali dalam aspek pendidikan. Dengan perkembangan teknologi yang semakin pesat, tentunya hal tersebut baik secara langsung maupun tidak langsung akan menjadi tantangan tersendiri bagi para siswa. Pendidikan 4.0 tidak hanya berfokus pada pemanfaatan teknologi, akan tetapi minat baca siswa juga perlu ditingkatkan untuk menyongsong pendidikan 4.0. Derasnya arus informasi dan teknologi di era pendidikan 4.0 ini berdampak pada semakin terbatasnya waktu yang dimiliki para siswa untuk membaca. Padahal, kemampuan literasi siswa dalam membaca tentunya dapat sangat diperlukan bagi siswa untuk tetap dapat mengikuti segala perkembangan terutama yang terkait dengan dunia pendidikan mereka. (Yuriza, Adisyahputra, \& Sigit, 2018).

Pada saat ini sesungguhnya para siswa dihadapkan pada pada persoalan bagaimana mengatasi keterbatasan waktu dan dapat membaca dalam waktu yang relatif singkat tetapi dapat memperoleh informasi yang sebanyak-banyaknya (Rahmania et al., 2015). Bagaimana dapat melakukan kegiatan membaca secara efektif tanpa membuang-buang waktu. Selaras dengan pernyataan tersebut, terlihat bahwa kemampuan literasi membaca sangatlah dibutuhkan para siswa seiring dengan pesatnya perkembangan informasi dan teknologi di masa sekarang ini.

Hanggi (2016) menyatakan bahwa literasi membaca dapat menjadi sarana bagi siswa dalam mengenal, memahami, dan menerapkan ilmu yang didapatkan di sekolah. Literasi dasar, termasuk lilterasi membaca, sudah selayaknya perlu ditanamkan sejak pendidikan dasar (Ristanto, Zubaidah, Amin \& Rochman, 2017). Hal tersebut diperlukan supaya para siswa dapat meningkatkan kemampuannya dalam upaya mengakses informasi ataupun ilmu pengetahuan. 
Literasi Budaya dan Kewargaan

Menurut TIM GLN (2017) literasi budaya merupakan kemampuan dalam memahami dan bersikap terhadap kebudayaan Indonesia sebagai identitas bangsa. Sementara itu, literasi kewargaan adalah kemampuam dalam memahami hak dan kewajiban sebagai warga negara. Dengan demikian, literasi budaya dan kewargaan merupakan kemampuan individu dan masyarakat dalam bersikap terhadap lingkungan sosialnya sebagai bagian dari suatu budaya dan bangsa. Literasi budaya dan kewargaan Menurut Kemendikbud (2016) menjadi hal yang penting untuk dikuasai di abad ke-21. Indonesia memiliki beragam suku bangsa, bahasa, kebiasaan, adat istiadat, kepercayaan, dan lapisan sosial. Sebagai bagian dari dunia, Indonesia pun turut terlibat dalam kancah perkembangan dan perubahan global. Oleh karena itu, kemampuan untuk menerima dan adaptasi, serta bersifat secara bijaksana atas keberagaman ini menjadi sesuatu yang mutlah.

Menurut Antoro (2017) literasi budaya dan kewargaan mempunyai jumlah dan ragam sumber belajar yang bermutu yakni program menulis buku dan pengayaan bahan cerita lokal dan nasional. Jumlah dan ragam sumber belajar literasi budaya dan kewargaan sebagai berikut:

1. Program Menulis Buku tentang literasi budaya dan kewargaan bagi warga sekolah secara tidak langsung dapat membantu siswa memperkaya bahan bacaan. Selain itu, menulis tentang literasi budaya dan kewargaan juga merupakan salah satu cara untuk melestarikan nilai-nilai budaya dan kewargaan.

\section{Pengayaan Bahan Cerita Lokal dan Nasional}

Siswa perlu diperkenalkan bacaan lokal dan nasional. Bacaan lokal penting agar siswa mengetahui karya sastra daerah yang dilahirkan nenek moyangnya dan juga para penulis yang hidup pada masa kini. Penting bagi siswa untuk mengetahui nilai dan pesan yang bersumber dari daerahnya sendiri. Sementara itu, bahan cerita nasional juga tidak kalah penting bagi siswa untuk mengenali keanekaragaman kisah dari berbagai penjuru tanah air. Cerita nasional dapat bersumber dari cerita daerah dari daerah lain atau cerita terkini (sastra modern) yang dihasilkan sastrawan Indonesia.

Literasi budaya dan kewargaan dapat diperluas atau diperkuat dengan melibatkan publik seperti membuat festival seni pelajar, melibatkan kegiatan kepramukaan, merayakan momen penting/hari nasional, mengadakan kegiatan bulan literasi budaya dan kewargaan. 
Menurut Antoro (2017) Strategi dalam gerakan literasi budaya dan kewargaan sekolah sebagai berikut:

1. Bengkel Kreatif Berbahasa Daerah adalah sarana paling penting untuk mendorong budaya tulis dan siswa yang literat di sekolah. Di bengkel kreatif, siswa akan mengeluarkan bakat dan minatnya menjadi kreatif, siswa akan mengeluarkan bakan dan minatnya menjadi karya nyata di bidang lisan, tulisan, audio, dan visual. Siswa dapat memanfaatkan sarana digital sebagai sarana belajar, sumber belajar, dan publikasi karya.

2. Residensial Residensial adalah sebuah program yang membawa siswa ke suatu komunitas/masyarakat dalam beberapa waktu dengan tujuan mengetahui proses bermasyarakat, berproses, dan berkarya. Siswa akan tinggal bersama masyarakat dan mengalami langsung sebuah penyesuaian hidup sebagai pengalaman otentik. Pada akhirnya, siswa dapat menuangkan pengalamanya dalam bentuk tulisan dan laku kreatif lainnya.

3. Pelatihan Guru dan Tenaga Kependidikan

Pelatihan bagi guru dan tenaga kependidikan bertujuan untuk memperkaya pengetahuan dalam mengaplikasikan literasi budaya dan kewargaan dalam pembelajaran. Mengintegrasikan kecakapan literasi budaya dan kewargaan dalam pembelajaran bertujuan untuk membentuk karakter siswa agar dapat memahami, menghormati, menghargai, serta melindungi kebudayaan dan kesatuan bangsa.

Menurut Antoro (2017) pembelajaran literasi tidak akan berhasil tanpa adanya penguatan dari tata kelola dalam sekolah. Penguatan tata kelola dalam pembelajaran literasi sebagai berikut :

1. Pembentukan Tim Literasi Sekolah

Tim literasi sekolah terdiri atas kepala sekolah, pengawasan, guru, dan wakil orang tua peserta didik dengan tugas memantau berjalannya kegiatan-kegiatan literasi di sekolah.

2. Pembuatan Kebijakan Sekolah

Adanya kebijakan sekolah yang menyatakan pentingnya literasi budaya dan kewargaan akan mempengaruhi keberhasilan penerapan literasi budaya dan kewargaan yang ada di sekolah.

3. Penguatan Peran Komite Sekolah

Komite sekolah dapat memberikan dukungan dalam kelancaran penerapan literasi budaya dan kewargaan di sekolah. Untuk membangun relasi kerja sama dan komitmen di dalam kegiatan literasi, komite sekolah dapat memperkaya relasi dengan pihak luar dalam hal membantu pelibatan publik. 


\section{Metode}

Penelitian ini menggunakan pendekatan kualitatif. Jenis penelitian ini adalah kualitatif deskriptif. Lokasi penelitian ini di SMP Negeri 1 Jember. Penentuan informan menggunakan teknik purposive. Menurut Eri (2016) purposive adalah teknik penentuan sampel berdasarkan pertimbangan tujuan yang telah ditetapkan oleh si peneliti, karena itu pengambilan sampel secara purposive tidak memperhatikan prinsip keterwakilan dari pupulasi. Teknik pengumpulan data dengan wawancara, observasi dan dokumentasi. Menurut Suyitno (2018) teknik observasi merupakan suatu kegiatan yang bisa dihubungkan dengan upaya merumuskan masalah dan membandingkan masalah untuk menemukan strategi pengambilan data dan bentuk perolehan pemahaman yang idanggap paling tepat. Menurut Sugiyono (2016) teknik wawancara merupakan pertemuan dua orang untuk menerima informasi melalui tanya jawab. Menurut Sugiyono (2016) metode dokumentasi adalah teknik mencari data mengenai hal-hal yang berupa catatan transkip, buku, surat kabar, majalah, prasasti, notulen, agenda dan lainnya

Analisis data menggunakan model interaktif Miles, Huberman dan Saldana mulai dari kondensasi data (menyeleksi dan memfokuskan), mengabstrasikan, menyederhanakan dan mentransformasi, penyajian data, dan penarikan kesimpulan dan verifikasi. Menurut Sugiyono (2016) analisis data merupakan proses mencari dan menyusun secara sistematis data yang diperoleh dari hasil wawancara, catatan lapangan, dan dokumentasi dengan cara mengorganisasikan data dalam kategori, menjabarkan ke unit-unit, melakukan sintesa, menyusun kedalam pola, memilih mana yang penting serta membuat suatu kesimpulan sehinga mudah dipahami oleh diri sendiri dan orang lain.

Menurut Sugiyono (2016) triangulasi dalam pengujian kredibilitas diartikan dengan berbagai cara dan berbagai waktu. Dengan demikian terdapat triangulasi sumber, triangulasi teknik, dan triangulasi waktu. Keabsahan data pada penelitian ini mengunakan triangulasi sumber dan triangulasi teknik. Triangulasi sumber dalam penelitian dilakukan dengan cara mengecek data yang telah diperoleh dari beberapa sumber yakni dari Kepala Sekolah, Koordinator literasi, Guru IPS, dan peserta didik sedangkan triangulasi teknik dalam penelitian dilakukan dengan cara mengecek data yang telah diperoleh dari beberapa metode yakni dengan metode observasi, metode wawancara, dan metode dokumentasi.

\section{Hasil \& Diskusi}

Hasil penelitian ini difokuskan pada pelaksanaan pembelajaran literasi membaca dan pelaksanaan pembelajaran literasi budaya dan kewargaan di SMP Negeri 1 Jember yang dilakukan melalui beberapa kegiatan di antaranya sebagai berikut : 
Pelaksanaan pembelajaran literasi membaca di SMP Negeri 1 Jember

Pelaksanaan pembelajaran literasi membaca di SMP Negeri 1 Jember sudah mulai ada sejak tahun 2017. Pelaksanaan pembelajaran literasi ini diawasi oleh kepala sekolah dan dibentuk tim untuk menangani khusus dalam pelaksanaan pembelajaran literasi. Tim literasi itu sendiri dibentuk dari perkumpulan guru-guru yang mengampu mata pelajaran Bahasa Indonesia yang mana terdiri dari 6 guru Bahasa Indonesia yang masuk dalam tim literasi. Pelaksanaan pembelajaran literasi dilaksanakan bermula dari adanya intruksi dari pemerintah pusat lalu ditindak lanjuti dari pihak sekolah lalu dibentuklah tim yang manangani literasi lalu disusun program-program kegiatan dalam pelaksanaan pembelajaran literasi yang bervariasi. Hal ini sesuai dengan hasil wawancara yang dilakukan kepada Ibu Tutut Winarni selaku koordinator literasi bahwa:

"Pembelajaran literasi di SMP Negeri 1 Jember mulai ada sejak tahun 2017 yang dibentuk melalui adanya intruksi dari pemerintah yakni GLS (Gerakan Literasi Sekolah) lalu sekolah memutuskan untuk memprogramkan kegiatan pembelajaran literasi yang mana dalam pembelajaran literasi dibentuk tim khusus yang menanganinya. Pembentukan tim literasi yang masuk di dalamnya yakni guru Bahasa Indonesia dibantu guru kesiswaan dan guru-guru yang lainnya. Selain itu, di SMP Negeri 1 Jember ini dulunya minat membaca anak-anak sangat kurang hal ini karena faktor teknologi yang sangat canggih sehingga anak-anak lebih suka bermain gadget dari pada untuk membaca buku. Oleh karena itu, bersamaan dengan perintah dari pemerintah dan fakta dilapangan yang memprihatinkan maka SMP Negeri 1 Jember memutuskan memprogramkan kegiatan pembelajaran literasi".

Kemudian Ibu tutut winarni memaparkan beberapa kegiatan-kegiatan yang dilakukan dalam pelaksanaan pembelajaran literasi membaca di SMP Negeri 1 Jember, di antaranya sebagai berikut:

"Pelaksaaan pembelajaran literasi membaca yang sudah dijalankan SMP Negeri 1 Jember terdiri dari beberapa kegiatan yakni kegiatan pembelajaran literasi membaca senyap kelas VII, VIII, IX lalu menulis kembali hasil tentang buku yang sudah dibaca di buku jurnal sesuai dengan bahasa mereka, mengumpulkan tagihan resum dari buku yang sudah dibaca setiap akhir semester, membuat pojok baca, pembelajaran literasi hari wajib meminjam buku, dan kegiatan literasi membaca di luar kelas (taman baca)". 
Pelaksanaan pembelajaran literasi membaca di SMP Negeri 1 Jember di antaranya:

a. Pelaksanaan kegiatan pembelajaran literasi membaca senyap

Pelaksanaan pembelajaran literasi membaca senyap dilaksanakan setiap hari selasa, rabu, dan kamis. Pelaksanaan pembelajaran literasi membaca senyap ini diikuti oleh semua warga kelas yakni dari kelas VII, VIII, dan IX. Pelaksanan pembelajaran literasi membaca senyap dilaksanakan setiap pagi sebelum kegiatan belajar mengajar dimulai yang diberi durasi 15 Menit. Guru yang mengawasi dalam pelaksaanan pembelajaan literasi membaca senyap itu sendiri dari guru yang mengajar pada masingmasing kelas di jam pertama.

Guru yang mempunyai jadwal mengajar diawal memiliki wewenang akan pelaksanaan pembelajaran literasi membaca senyap. Setelah selesai membaca buku yang telah ditentukan peserta didik bergegas untuk menulis kembali apa yang sudah mereka baca sesuai dengan bahasa mereka ditulis pada buku jurnal literasi dengan seperti itu peserta didik akan menghasilkan hasil tulisan dari membaca senyap. Setelah itu bagi peserta didik yang telah menyelesaikan pembelajaran literasinya yakni membaca senyap dan menuliskan di buku jurnal literasi selanjutnya mereka kumpulkan pada guru yang mengajar di jam pertama untuk meminta tanda tangannya sebagai tanda bukti bahwa telah menyelesaikan literasi membaca senyap dan menuliskan kembali pada buku jurnal.

Buku yang digunakan dalam pelaksanaan pembelajaran literasi membaca senyap untuk kelas VII, VIII, dan IX memiliki kategori buku yang berbeda setiap kelasnya. Apabila kelas VII yang dibaca adalah buku fiksi yang mana buku tersebut kategori buku ringan yang bisa membangkitkan minat siswa, kelas VIII yang dibaca adalah buku fiksi yang mana buku tersebut tentang novel pendidikan, kelas IX yang dibaca adalah buku nonfiksi yang mana buku tersebut tentang pendidikan, motivasi, biografi, dan lain-lain, dan untuk guru yang ada di jam pertama mengawasi pelaksanaan pembelajaran literasi membaca senyap.

b. Literasi membaca 4 buku setiap 1 semester

Pelaksanaan pembelajaran literasi membaca 4 buku setiap 1 semester ini dilakukan untuk memberikan tambahan wawasan kepada peserta didik agar mereka semakin banyak lagi untuk membaca dan agar mereka membudayakan membaca. Dengan cara itu peserta didik dapat membiasakan dirinya untuk suka membaca. Pembelajaran literasi membaca 4 buku setiap 1 semester ini dilaksanakan di luar pembelajaran. Dilakukan dengan sistem penugasan yang dikerjakan di rumah. Pembelajaran literasi membaca ini biasanya dilaksanakan setiap akan memasuki ujian akhir sekolah (UAS). Pembelajaran literasi yang ini dilaksanakan dalam bentuk 
penugasan yang diberi jangka waktu sekitar 3 minggu untuk menyelesaikan 4 buku yang harus sudah dibaca. Setelah 4 buku tersebut selesai dibaca maka peserta didik diminta untuk meresum hasil dari apa yang sudah mereka baca, dituliskan kembali menurut bahasa mereka sendiri.

c. Pembelajaran literasi membaca dengan sistem hari wajib berkunjung perpustakaan

Hari wajib perpustakaan ini dilaksanakan setiap hari akan tetapi ada jadwal tertentu untuk menentukan kelas mana yang mempunyai kewajiban untuk berkunjung ke perpustakaan. Namun meskipun sudah dijadwalkan pada masing-masing kelas bukan berarti untuk kelas lain yang tidak terjadwal pada hari itu tidak boleh berkunjung ke perpustakaan. Untuk hari wajib berkunjung ke perpustakaan ada jadwal sendiri yang sudah dijadwalkan oleh tim literasi. Untuk hari Senin dan Kamis bagian kelas IX A, B, C, D, E, F, G, H, I, dan J. Untuk hari Selasa dan Jum'at bagian kelas VII A, B, C, D, E, F, G, dan H. Untuk hari Rabu dan Sabtu bagian kelas VIII A, B, C, D, E, F, G, H, I, dan J. Jadwal berkunjung perpustakaan itu wajib mereka gunakan sesuai jadwal yang telah ditentukan dengan didampingi guru Bahasa Indonesia yang mengajar pada masing-masing kelas.

d. Pembelajaran literasi membaca di luar kelas

Pembelajaran literasi membaca di luar kelas ini dilakukan setiap 1 bulan sekali dengan tujuan agar peserta didik tidak bosan dalam melaksanakan pembelajaran literasi yang hanya di dalan kelas saja. Untuk prosedur yang digunakan dalam pembelajaran literasi membaca di luar kelas sama dengan prosedir pembelajaran literasi membaca senyap.

e. Membuat pojok baca

Pojok baca adalah sebuah tempat yang ada di ruangan yang biasanya ada di paling sudut atau paling pojok kelas. Pojok baca ini berperan sebagai perpajangan fungsi perpustakaan melalui tempat menyimpan buku yang ada pada masing-masing kelas. Melalui pojok baca para peserta didik dilatih untuk membiasakan gemar dan suka akan membaca buku. Dalam pembuatan pojok baca ini sifatnya dilombakan. Setiap kelas wajib membuat pojok baca dengan kreatif, bagus, indah sesuai dengan keinginan dalam masing-masing kelas.

Pelaksanaan pembelajaran literasi budaya dan kewargaan.

Pelaksanaan pembelajaran literasi budaya dan kewargaan di SMP Negeri 1 Jember sudah mulai ada sejak tahun 2018. Pelaksanaan pembelajaran literasi budaya dan kewargaan ini sama dengan pembelajaran literasi membaca yang mana diawasi oleh kepala sekolah dan dibentuk tim untuk menangani khusus dalam pelaksanaan pembelajaran 
literasi. Pelaksanaan pembelajaran literasi budaya dan kewargaan yang sudah dijalankan SMP Negeri 1 Jember ini juga bermacam-macam. Hal itu untuk menunjang keberhasilan SMP Negeri 1 Jember untuk mensukseskan pelaksanan pembelajaran literasi. Hal ini sesuai dengan pemaparan Ibu Tutut Winarni selaku koordinator literasi bahwa:

"Pelaksaaan pembelajaran literasi budaya dan kewargaan yang sudah dijalankan SMP Negeri 1 Jember terdiri dari beberapa kegiatan yakni kegiatan literasi presentasi, lomba mading kelas, lomba menulis puisi tema pahlawan dan sumpah pemuda, pameran kebudayaan, dan bazar buku".

Pelaksanaan pembelajaran literasi budaya dan kewargaan di antaranya yakni:

a. Pelaksanaan literasi presentasi

Pelaksanaan literasi presentasi adalah literasi yang dilaksanakan khusus untuk kelas IX yang dilaksanakan setiap hari sabtu sepulang sekolah dengan kuota 1 hari untuk 3 siswa dengan durasi waktu 3-5 menit. Guru yang mengawasi adalah guru yang mengajar pada mata pelajaran hari Sabtu pada jam terakhir. Hasil penilaian disetor bila sudah lengkap satu kelas kepada guru mata pelajaran Bahasa Indonesia yang mengajar.

b. Lomba mading kelas

Lomba mading kelas dilaksanakan setiap 1 semester sekali. Lomba mading kelas ini dilaksanakan dengan tema provinsi yang ada di Indonesia. Tema ini dijadikan lomba dalam pelaksanaan mading kelas karena dengan seperti itu peserta didik secara tidak langsung akan banyak belajar dari apa yang mereka kerjakan dalam membuat mading kelas. Mading kelas yang bertemakan provinsi di dalamnya harus terdapat kebudayaan di provinsi itu sendiri seperti makanan khas, lagu daerah, tarian tradisional, rumah adat, baju adat, suku, dan lain sebagainya.

c. Lomba literasi menulis puisi tema hari pahlawan dan sumpah pemuda

Kegiatan lomba-lomba menulis puisi tema hari pahlawan dan sumpah pemuda ini dilaksanakan 1 tahun sekali ketika bertepatan pada hari sumpah pemuda dan hari pahlawan. Kegiatan lomba ini dilaksanakan untuk semua kelas dari kelas VII, VIII, dan IX.

d. Pameran literasi budaya

Pelaksanaan pameran budaya dilaksanakan setiap akhir semester. Kegiatan ini dilaksanakan agar peserta didik mampu bersikap terhadap budaya Indonesia sebagai identitas bangsa dan dilaksanakan sebagai tambahan kegiatan dalam menunjang keberhasilan pembelajaran literasi budaya dan kewargaan. 
e. Bazar buku

Pelaksanaan bazar buku dilaksanakan bersamaan dengan pameran literasi budaya yakni setiap akhir semester. Bazar buku yang dipamerkan tidak asal semua buku melainkan ada tema khusus yang diangkat sehingga buku yang dibazarkan sesuai dengan tema tersebut.

\section{Kesimpulan}

Berdasarkan hasil penelitian dapat disimpulkan bahwa pelaksanaan pembelajaran literasi membaca di SMP Negeri 1 Jember dilaksanakan dengan beberapa kegiatan yaitu pelaksanaan kegiatan pembelajaran literasi membaca senyap yang dilaksanakan setiap hari selasa, rabu, dan kamis dengan durasi waktu 15 Menit sebelum kegiatan belajar mengajar dimulai, literasi membaca 4 buku setiap 1 semester dilaksanakan setiap akan melaksanakan ujian akhir semester dengan durasi mengerjakan sekitar 3 minggu, pembelajaran literasi membaca dengan sistem hari wajib berkunjung perpustakaan dilaksanakan setiap hari sesuai dengan jadwal yang telah ditentukan, pembelajara literasi membaca di luar kelas dilaksanakan setiap 1 bulan sekali dengan tujuan agar peserta didik tidak bosan dalam melaksanakan pembelajaran literasi yang hanya didalam kelas saja, dan membuat pojok baca yang dilaksanakan setiap 1 semester sekali dengan sistem dilombakan antar kelas.

Pelaksanaan pembelajaran literasi budaya dan kewargaan di SMP Negeri 1 Jember dilaksanakan dengan beberapa kegiatan yaitu pelaksanaan literasi presentasi yang dilaksanakan khusus untuk kelas IX setiap hari sabtu sepulang sekolah dengan kuota 1 hari untuk 3 peserta didik dengan durasi waktu 3-5 menit, lomba mading kelas dilaksanakan setiap 1 semester sekali dengan sistem dilombakan antar kelas, lomba literasi menulis puisi tema hari pahlawan dan sumpah pemuda dilaksanakan setiap 1 tahun sekali bertepatan pada hari sumpah pemuda dan hari pahlawan, pameran literasi budaya dilaksankaan setiap akhir semester atau setelah kegiatan ujian semester, dan bazar buku dilaksanakan setiap akhir semester atau setelah kegiatan ujian semester dan bersamaan dengan pelaksanaan pameran literasi budaya.

\section{Referensi}

Abidin, Y. (2015). Pembelajaran Multiterasi. Refika Aditama.

Abidin, Y. (2017). Pembelajaran Literasi Strategi Meningkatkan Kemampuan Literasi Matematika, Sains, Membaca, dan Menulis. Jakarta: Bumi Aksara.

Antoro, B. (2017). Gerakan Literasi Sekolah Dari Puncak Hingga Akar. Jakarta: Direktorat Jenderal Pendidikan Dasar dan Menengah Kementerian Pendidikan dan Kebudayaan. 
Aziz, A. (2018). Landasan Pendidikan. Pamulang: Haja Mandiri

Dikdasmen, D. (2016). Desain Induk Gerakan Literasi Sekolah. Jakarta: Direktorat Jenderal Pendidikan Dasar dan Menengah Kementrian Pendidikan dan Kebudayaan.

Handayani, G., Adisyahputra, \& Indrayani, R. (2018). Correlation Between Integrated Science Process Skills, and Ability to Read Comprehension to Scientific Literacy in Biology Teachers Students. Biosfer: Jurnal Pendidikan Biologi, Vol. 11 No. 1, 22-32

Hanggi, O. H. (2016). Tiga Perubahan Kecil dalam Literasi Sekolah "Membumikan Gerakan Literasi di Sekolah.” Lembaga Ladang Kata.

Kemdikbud, \& Nasional, G. L. (2017). PANDUAN GERAKAN LITERASI NASIONAL.

Rahmania, S., Miarsyah, M., \& Sartono, N. (2015). View of The Difference Scientific Literacy ability of Student having Field Independent and Field Dependent Cognitive style. Biosfer: Jurnal Pendidikan Biologi, Vol 8 No. 2, 27-34

Sugiyono. (2016). Metode Penelitian Kuantitatif Kualitatif. Bandung : Alfabeta.

Suyitno. (2018). Metode Penelitian Kualitatif: Konsep, Prinsip, dan Operasionalnya. Tulungagung: Akademia Pustaka 